\title{
Cartographies of disappearance: Thresholds in Barcelona's metro
}

Enric Bou, Università Ca’ Foscari Venezia

\begin{abstract}
This article proposes an analysis of Barcelona's metro system following David Pike's threshold concept, key to the topography of the 'vertical city'. This will be done through reading maps and literary texts that illustrate three closely related issues: an interpretation of Barcelona's metro network and its meanings; the disappearance of some metro stations and underground spaces, such as hidden connecting corridors, which create a shallow presence of the past into the present, examples of urban spaces that are buried and forgotten; and subway life as portrayed in some literary texts with particular emphasis on the use of mythology.
\end{abstract}

\section{Keywords}

metro systems

urban literature

everyday life

disappearance

ghost stations

maps

Barcelona

In June 2013, I visited - with my son - the exhibition celebrating the 150th anniversary of the Tren de Sarrià (Sarrià Train), formerly known as Els Ferrocarrils Catalans (Catalan Railways). The exhibit took place at the site of a former cinema called Avenida de la Luz (Avenue of Light). Since 1979, the railway has become a public-owned company, and it is now called, 
less compromisingly, FGC: Ferrocarrils de la Generalitat de Catalunya (Generalitat of Catalonia Railways) (fgc150 2013). I was unpleasantly surprised by the self-celebratory nature of the exhibition and how little attention was given to a critical reading of the past. Trying to explain the meaning of FGC to my son, immediately a variety of texts came to mind that provided a different version of Barcelona's metro. I also thought of all those hidden underground empty spaces, or those redesigned for a new use, that populate our cities. It was easy to make the connection because we were at the site of a former cinema and next door to the former and once flamboyant avenue bearing the same name that was inaugurated in 1940 and closed in disarray in 1990. It had been converted into a place for drug dealing and treacherous encounters, and is now a dreary Sephora store.

In this article my attention is devoted to three interrelated issues: the layout of Barcelona's network and its meanings; the disappearance of some metro stations and underground spaces such as connecting corridors; and Barcelona subway life as portrayed in literary texts. These are texts that have something in common: they depict metro riding as an experience analogous to exploring the inner self, exposing the many absurdities in life. In addition, they draw upon mythological references to imbue the metro experience with a more positive aura. On the other hand, the writers considered here pay attention to the lack of natural light in the underground and the confluence of people from many backgrounds and circumstances within a closed space, thus creating a sort of temporary melting pot that stresses divergence and conflict. These writers acknowledge the dialectical interrelations between the built environment and the urban consciousness, leaving room for oppositional forms of consciousness (Masterson-Algar 2014: 70). David Pike's threshold concept provides a helpful explanation for the topography of the 'vertical city' because 'it figures the ways in which the two spaces [aboveground and underground] overlap and the ways in which they remain fundamentally different' (2007: 64). The texts and spaces examined provide a 
threshold that 'figures the moments that link aboveground and underground, where what is hidden emerges into visibility' (Pike 2005:16).

\section{Notes on Barcelona's metro system}

A city's metro system is a unique piece of its environment that links two aspects of urban space. As stated by Lewis Mumford, 'the modern city plan involves a coordination of the super-surface city with the sub-surface city' (quoted in Williams 2008: 52); there is a direct connection between our wide knowledge of the surface and very limited knowledge of the urban underworld. According to Ashford, '[t]he Underground is a transitional form, linking the alienated space of production created by the Industrial Revolution to the fully virtual spaces of late capitalism that emerged following the Cold War' (2013: 2). Development of Barcelona's underground transportation has been the result of disparate initiatives and bad planning, which shows through in its topsy-turvy layout and current condition.

${ }^{1}$ Tracing the many changes that Barcelona's rail system has undergone reveals that even as the metro came to be a mirror for collective wishes and frustrations it persistently lacked coherence.

The first application for the construction of a railway between Barcelona and the nearby town of Sarrià was filed in 1851, three years after the opening of the first railway line connecting Barcelona and Mataró. The Sarrià train began operating in 1863, the same year as the London Underground. It was a short line, only 4600 metres in length, starting in what is today known as the Plaça de Catalunya (Catalonia Square), and crossing Barcelona through the villages of Gràcia and Sant Gervasi to arrive in Sarrià, at the foot of the Collserola mountain. For many decades, the trains were operated by steam locomotives, but in 1905 , with the gradual development of the Eixample district, they were upgraded to electrical 
locomotives, as described by Joan Maragall. In his article 'L'últim xiscle' (The last cry), Maragall stresses change and loss, and thus disappearance of a way of life:

L'endemà - ja ho havia llegit en el diari - l'endemà començava la tracció elèctrica. Ja no'l sentiriem xiular mai més aquell tren de Sarrià: aquell xiscle era un adéu; el tren se'n anava no cap a Sarrià, sino cap ala eternitat: no'l tornariem a sentir mai més. ('The next day - I had already read about it in the newspaper- next day began electric traction. Since we would not listen ever again to the train of Sarrià whistle: that was a goodbye scream; it was not the train of Sarrià, but to eternity: we would not listen it ever again.) (Maragall 1912: 155)

The Sarrià train became the first electric railway in Catalonia. The engineer Carles Emili Montañés convinced Frederick S. Pearson, an engineer from Lowell, Massachussetts, to purchase the Sarrià-Barcelona line and its extension towards Vallès. In 1912, it was incorporated as Ferrocarriles de Cataluña (Catalonia Railways). In 1917, the company opened the double track to Sant Cugat del Vallès. In 1919 the line reached Terrassa, and Sabadell in 1922. The line ran on the surface until 1929 when the section Catalunya-Muntaner was buried. In 1953, a branch from Gràcia to Avinguda Tibidabo was inaugurated. The urban lines became L6 and L7 (fgc150 2013). When the line was buried it got the attention of a sharpsighted journalist named Gaziel, who in a memorable article, 'Pequeña elegía urbana (Little Urban Elegy)', evoked his personal relationship with the Sarrià train. In the article, he recalls the 40 years since he started using the line, the impact of industrialization on ways of life, ending with a characteristic Gaziel observation, longing or imagining (or assuming) what the future may bring: 
¿Es un sueño? No; es algo parecido: cuarenta años de vida. [...] Al constatar sus extraordinarias mudanzas es forzoso sentir que, en nuestra brevedad, todo lo que fuimos en el seno de esa vida municipal gigantesca, se borra paulatinamente, y nuestra propia vida se va convirtiendo poco a poco en estampas del tiempo pasado [It is a dream? No. It is something similar: forty years of life. [...] When acknowledging its extraordinary changes you must feel that in our brevity, everything that we witnessed within that giant municipal life, is gradually erased, and our life is becoming gradually prints from the past. (Gaziel 1929)

Gaziel's elegy for a time past emphasizes the speed at which changes occur, resulting in a fragile awareness of transience: we are meant to be swallowed and disappear. He does not notice the fact that there is an important transformation in city life: the underground swallows a former surface train. Demolition and erasure bring with them a sudden appreciation of what is no longer there, and this is a distinctive feature of our experience of the modern cityscape: 'perpetual change erases memory'. The endless quest for novelty merges into the flow of undifferentiated, empty time where the past is consigned to oblivion by the present, and perhaps most importantly it may fleetingly reappear as a disturbance that gives a shock to today's passer-by (Gilloch 2004: 300). This peculiarity is particularly eloquent in the slow transformation of city underground life. Circulating underground, that line lost its character as an urban train and became a real metro.

Gran Metropolitano de Barcelona (Barcelona’s Big Metro, known as Gran Metro) was created on 26 May 1921 to construct and operate a subway line, now called L3. On 30 December 1924 the section between Lesseps and Catalonia was inaugurated (Reyes 2014). It had a length of $2470 \mathrm{~km}$ and four stations. Initially the project was to connect La Bonanova 
with Estació de França, but this never materialized. In 1926 a new branch was added. From Aragó station one branch would go to Liceu (it became later L3), and the other one to Correos (The Post). This second was converted in the 1980s into L4.

Metro Transversal began as an underground electric traction railway with the goal of establishing a transversal connection between the stations of the Barcelona-Tarragona and Barcelona to France railway lines (currently underused Estació de França, France's Station) and the other train stations: Estació del Nord (North Station), Estació Magòria (Magòria Station) (narrow-gauge railway to Berga), Estació P. Catalunya (Ferrocarrils Catalans, Catalan Railways). The first section was built to link the city centre with the Plaça d'Espanya (Spain's Square), the site of the 1929 World Fair. The official opening of the first section (Bordeta-Catalonia) was on 10 June 1926. It was named Metro Transversal to differentiate it from the Gran Metro, and was 4063 metres long and had nine stations. The station Espanya at that time had the world's largest station vault (27 metres). Because of its origins (connecting train stations) a particularity of this metro line is the use of the Iberian gauge of $1672 \mathrm{~mm}$, which makes it one of the widest in the world. Carriages from this line cannot circulate on other Barcelona lines. Between 1935 and 1950 there were no new stations built. In 1959 a new short line known as L5 was built, and in 1973 L4 was added (Salmerón i Bosch 1992; Schwandl 2001; Guerola 2004).

The return to democracy in 1977 made the public use of Catalan possible, and a call for self-government. Thus, it introduced significant changes in Barcelona's metro system. Local authorities had more direct control over planning decisions. During the 1980s there were substantial changes, not in terms of growth but in the identity and the ability to do longterm planning. First, lines III and IIIb (Pueblo Seco-Zona Universitaria) became the new L3. On the other hand, Roman numerals became Arabic numerals respecting in any case the old numeration. Colour-coded lines were introduced, and finally several station names were either 
translated into Catalan or renamed. The rationalization of public transportation included the creation of the t-10 card, which was accepted in all metro lines and buses. The following chart summarizes the most important name changes.

\begin{tabular}{|c|c|c|}
\hline L1 & Former name & New name \\
\hline & Navas de Tolosa & Navas \\
\hline & Triunfo Norte & Arc de Triomf \\
\hline & Bordeta Cocheras & Santa Eulàlia \\
\hline $\mathbf{L 3}$ & Ciudad Universitaria & Zona Universitària \\
\hline & Palacio & Palau Reial \\
\hline & Roma Estación Renfe & Sants Estació \\
\hline & Parlament & Poble Sec \\
\hline & Pueblo Seco & Paral·lel \\
\hline & Aragó & Passeig de Gràcia \\
\hline & Diagonal-Paseo de Gracia & Diagonal \\
\hline L4 & & \\
\hline & General Mola & Verdaguer \\
\hline & Ribera & Ciutadella \\
\hline & Pedro IV & Bogatell \\
\hline & Luchana & Llacuna \\
\hline $\mathbf{L 5}$ & & \\
\hline
\end{tabular}




\begin{tabular}{|l|c|c|}
\hline & Buxeras & Can Boixeres \\
\hline & Maladeta & Can Vidalet \\
\hline & San Ramón & Collblanc \\
\hline & Dos de Mayo & Hospital de Sant Pau \\
\hline & Viviendas del Congreso & Congrés \\
\hline
\end{tabular}

Overall, these changes reflect two trends: an attempt to correct for a politically tainted heritage, and a push towards recuperation of symbols after a long fascist dictatorship that had pointedly erased any traces of Catalan language and culture wherever possible. Two examples are particularly significant in this respect. First, General Mola, one of the generals who rebelled against the Republic, became Verdaguer, Catalonia's famous poet from the Renaixença (Renaissance); and second, Dos de Mayo, a commemoration of the Madrid rebellion against Napoleon, of little importance in Barcelona, became Hospital de Sant Pau, a landmark of modernista (Art Nouveau) architecture. ${ }^{2}$ If you compare Barcelona's metro layout, extension of the lines, and amount of stations with those of other cities of similar size, there are a number of stark differences (List of metro systems 2015).

One could say that the history of Barcelona's Metro is a tale of wishes and frustrations. If one considers the gaps between the project's conceptions, the desires of the planners, and the results that were obtained, it is clear that something strange has happened; the old saying that 'the Barcelona metro was developed by the enemy' is not so far from reality. A few examples should suffice to convey the magnitude of the disaster. There is no direct link between the city centre and Estació de França, which was for many years the main railway station in the city. Gran Metro was built with the idea of establishing that link, but this never happened, and travellers had to walk 800 metres to reach the station from the nearest metro stop. In Figure 2 we read a remarkable example of wishful thinking: riders 'only' need to take a four-minute walk to reach the Correos station from Estació de França. Connections between 
many stations seem the work of shrewd labyrinth designers. Most notably is the connection between L3 and L4 in Passeig de Gràcia (formerly Aragó), where subway users are supposed to walk underground for more than $500 \mathrm{~m}$, or the connection between L7-L8 and L1 in Catalunya, where users have to walk for miles or navigate dangerously through incoming L3 trains and rushing passengers. This kind of basic metro map hides a more complex reality that the universal use of colour-coded lines and a rendition of paths on the city's real space tend to conceal.

Figure 1: Map Metro BCN 1925.

Figure 2: Map Metro BCN 1940’s.

Figure 3: Map Metro BCN 1966.

Figure 4: Map Metro BCN 1974.

Figure 5: Map Metro BCN 2015.

Comparing these five maps one sees the changes successively introduced in the layout of the network. Lines avoid the old part of town (only two lines cross it), and there is no direct link across the northern part of the city, thus increasing the isolation between different lines. The adoption of international standards with Beck's model to represent a metro network hides this gloomy reality (Pike 2005: 21-33).

Current historical accounts of Barcelona's metro system such as the one found in Carles Salmerón's book are excellent resources documenting the birth of an industry, the many changes in planning the lines, which types of cars and trains have been used over the years, the state of the fleet, etc. But we need an alternative critical history to discuss the shortcomings and errors of traditional cartography. Salmerón's approach matches Lefebvre's notion of planned space, conceived and dominated by the mechanism of the state: the 
infrastructure of trains and tunnels and all the personnel necessary to keep the metro operating. We need a complementary approach to this planned space. As put by Pike, '[o]verlapping and interacting with this conceived space are the rhythms of commuting that constitute everyday life in the modern city and the unforeseen, underground rhythms of that city [...] overlapping personal and social histories imbricated throughout the system' (2007: 13). The next section adopts Pike's approach to discuss examples of thresholds, noting instances of space disappearance and transformation and attending also to how writers have depicted the metro riding experience.

\section{Reading metro maps}

Current maps of Barcelona's metro hide the transformation of the network. They are meant to help current users navigate the system without any mention of what is hiding underneath, such as unused connecting corridors or closed stations. Many of these spaces still exist but they have been erased or transformed, and with them disappear memories, a way of living the city. Current subway maps are testament to a history of mismanagement and of missed opportunities, to a failure to create a city with a more coherent, useful and practical transport system. They hide the intricacy and difficulties of building the system, completely scratching out the past. Alternative mapping is required if these transformations are to become visible, if a history lesson is to be written into the city map. One example is what Víctor Balaguer did when he wrote Las calles de Barcelona (The streets of Barcelona) (1865), his proposal to name the still silent (unnamed streets) plan of Barcelona envisioned by Idelfons Cerdà, thus naming the Eixample streets according to historical references as a way to revive a neglected Catalonia's past (Quintana 2009; Subirana 2014). publication details of all the books mentioned in the text (except for those already included in the list). The first time the book is mentioned in the text, please insert the author's name, year of publication and insert only the year on the subsequent occurrences. 
Radical cartography or counter-mapping is an attempt to map against dominant power structures. It must provide products that satisfy the basic criteria of mapping: maps that are useful, usable and persuasive. It would have to introduce elements or approaches that were inaccessible, invisible, or perhaps even undesirable as seen through the lens of the existing schema (Denil 2011). The separation between the city above and the city underground is a 'topographical mnemonic' based on the symbolic topography of a single social space (Pike 2007: 63). Likewise, a new approach to Barcelona's metro map would reveal trends of disappearance and establish a cartographic picture of the past. ${ }^{3}$ Literature, on the other hand, would provide us with tools to map the experience and recall it from a diachronic and critical perspective.

Urban metro systems are an integral part of the lives of commuters and as such are ambiguous spaces, both familiar and threatening, reliable and unpredictable, crowded yet isolating, decisively subterranean yet linked to the geography of the city that lies above. An important tool in metro riding is the map we use to navigate a system. Subway networks are a special case in point when discussing the everyday. As Marc Augé put it, stressing the fact that subways link both physical spaces and human beings with all their complexity, 'Le métro relie des points algébriques, des lieux et des êtres' ('The metro connects algebraic points, places and things') (2008: 15). The everyday is not a region, a town, or a show that can be represented: without objective status, it only exists through practices that, by revealing its existence, make it happen. According to Blanchot, indeterminacy is the everyday's defining characteristic. The everyday escapes, that is its definition; it is the hardest thing to uncover (Sheringham 2006: 16). Metro maps may present a different window into the everyday.

When looking at a metro map we deal with two basic principles of typography: legibility and readability (Tracy 1986: 31). Legibility refers to perception and readability to comprehension. Legibility means, for example, that colour-coded lines are easily discernible 
between each other and station names can be read without difficulty. Readability, on the other hand, implies communicating a meaning as directly as possible, for example getting from point A to point B, what Duke Ellington's 'Take the A Train' song expresses so well. What I am pursuing here is another level of readability, one closer to Marc Augé's analysis. He points to daily rituals and other repetitive acts that metro users perform, thus explaining how the metro functions as a distinctive social space, with specific codes, rules and habits. Getting to know a city using the metro is a journey taken in accompanied solitude, a voyage through space and through a kind of geographically mapped collective unconscious. As Kafka wrote in his diary, the Métro was a way to capture the essence of Paris (Nervi 2011).

The metro network underpins the city, offering an experience of urban space that is very different from any other, because it provides a restricted underground view contingent on the topographical reduction of the city to a web of lines and correspondences. Augé comments on the way that metro riders organize their experiences in space and time: 'Subway riders basically handle nothing more than time and space, and are skilled in using the one to measure the other' (Augé 2002: 15). This is what Cortázar shows in 'El perseguidor' [The Pursuer], where the main character reflects on the way in which the metro brings a temporal flexibility into being. Johnny remembers moments of his life - many moments in his timeline, which encompasses fifteen minutes - that are now compressed into just a minute and a half, the time between two stops. This ability to mix different temporalities suggests the subway as a small time machine; it stops, spreads and takes us through a lonely temporal journey. For Cortázar, with the subway we immerse ourselves in a world created for observation and imagination. He looks at the metro as if it were a labyrinth under the earth, something that allows him to access another kind of time: 'sólo en el métro me puedo dar cuenta porque viajar en el métro es como estar metido en un reloj. Las estaciones son los minutos' ('only in 
the métro I am aware because riding the métro is like finding oneself in another kind of time. Stations are minutes') (Cortázar 1994: 233).

Ramon Solsona's novel Línia Blava (2004) seems to develop Marc Augé's view that on the metro 'we constantly brush up against the history of others [...] without ever meeting it' (Augé 2002: 10). The narrator describes a metro ride along the entire line 5 in Barcelona, emphasizing the subway as a place based on the inability to establish communication with others due to a self-imposed set of rules derived from the subway's system of connections and coincidences. The novel is organized by chapters whose titles chart the names of metro stations along Barcelona's blue line. The plot consists of parallel biographies, each one hiding its own little drama, using flashback and suspense and through an omniscient narrator who imagines the future of every single character he observes. Some lives end up intersecting, without any consequence. The novel recreates a form of mental activity or philosophical speculation in which many of us engage when facing unknown people: we may guess who they are, what their troubles are, what their futures may be, or even when they might die. Solsona's narrator builds a sort of kaleidoscope and focuses on a few characters that he observes, deducts trends, imagines a past, inner feelings, coincidences among them. A man and a woman - one a prostitute, the other an adopted immigrant from Central Africa - are interacting via a love cyberchat. The beginning and the end of the novel is organized around a threshold, stressing life outside the underground by paying attention to the free flight of birds, and thus denouncing the concealment and lack of fresh air below ground. There is also a selfreflective moment at the end of the novel when the narrator turns the tables around and offers to exchange views: 'Potser ella també ha fet volar la imaginació i, mentre tu li atribuïes una història, ella te n'atribuïa una altra' ('Maybe she also has played with her imagination and while you made up her story, she made up another one for yourself') (Solsona 2004: 300). In this way, the observer becomes the observed character. In the novel there is also a play with 
the metro map. A very well-known underground route is linked to imagined private lives, and in the process human experience intersects with urban underground geography. With painstaking detail he narrates how to use the metrocard and also the similarities between Sagrera and Horta stations that may lead to confusion: 'el viatger es desconcerta, té la sensació de retrobar-se a l'estació de partida' ('the rider feels puzzled and may think that he is back at the station of departure') (Solsona 2004: 71).

As depicted in Solsona's novel, metro riding is a major example of the monotony present in everyday life. There is a certain degree of consistency as '[m]ost of the singular itineraries in the subway are daily and obligatory' (Augé 2002: 8). Time and space constraints are crucial in defining the essential structures of subway riding, but there are also 'daily and obligatory' burdens that have a value at the individual level and are also experienced by the other riders. Augé focuses on socially significant uses of time and space offered by metro riding, as well as how these uses accommodate themselves to the specific symbolic matrices that are more noteworthy along particular lines, or as regards particular stations. For instance, he examines the naming of metro stations after military victories (Austerlitz and Solférino in Paris, Waterloo in London), and wonders whether this attests to the co-presence of history in our everyday lives or the unreality of history (Augé 2002: 16). Just as the monuments and squares of the city surface cease to have a meaning for those who pass through them every day, the historical connotations of familiar metro station names tend to disappear with time. In fact, they create new associations, series of names that sound almost as full sentences or paradigms, united according to their musicality or just chance.

A recent song by a Catalan rock band, Nens Eutròfics, explores this possibility: 'Subterrània' is a long list of all Barcelona metro stations organized according to rhythm and phonetics: 'Fondo, Fabra i Puig, Pàdua, Sant Martí / Selva de Mar, Horta, Gornal, Joanic' (Els Nens Eutròfics 2013). ${ }^{4}$ This list, bordering with Leo Spitzer's chaotic enumeration, provides a 
phonetic and puzzling version of Barcelona's metro map that can be read as a provocation, a sort of wake-up call to re-read in a different way a map encapsulating the space of everyday monotony. Moreover, the chaotic list of metro stations reminds us of the distinction between the world seen from above ('hierachized and conceptualized') and the world seen from below, one that 'revels in the sensation of its proximity to chaos' (Pike 2005 11). The subway map can be used in other innovative ways, such as a trigger for memories, a sort of pocket mirror in which will be reflected instantly birds from the past:

Sometimes the chance happening of an itinerary (of a name, of a sensation) is enough for distracted travelers suddenly to discover that their inner geology and subterranean geography of the capital city meet at certain points, where dazzling discoveries of coincidences promote recall of tiny and intimate tremors in the sedimentary layers of their memory. (Augé 2002: 4)

As Augé puts it, riding the metro creates new itineraries, therefore new topographies, mixing the past and the present, 'a slice of life of which the subway map, in the schedule we carry inside ourselves, reveals only a piece, the aspect simultaneously the most spatial and the most regular, but about which we know well that everything was or seemed to be in order' (2002: 9). The metro map indicates a blending of individual lives with those of others, private and public life, personal and collective stories. Another singer, Miquel Pujadó, has written a song titled 'Pels intestins de la ciutat' ('Through the city's intestines') in which he lists names of stations and makes them rhyme with actions and objects related to the metro riders he observes. Pujadó begins his song stressing the monotony of metro riding, the weariness of the riders, a situation that allows extreme mingling of people from very different social origins and backgrounds. He stresses the mixing of worlds and of humanity that takes place 
underground. Pujadó's text adds a notion of the everyday. After a crucial metaphor ('city’s intestines') he reveals the blending that takes place: mixed, crossing, weariness, intersections, tangent, secant, colliding, hence stressing the lack of cooperation between human beings. Hostility and indifference characterize human attitudes underground. He also builds riddles and play of words based on the musical combination of metro station names, alternating lines with two or three station names and lines with interrupted reflection on metro riding:

\author{
Arc de Triomf, Fondo, Espanya \\ Hi ha gent vulgar, gent estranya. \\ Poble Sec, Sant Roc, Entença \\ L'un parla sol, l'altre pensa. \\ Can Serra, Glòries, Vallcarca
}

Hi ha qui va llegint el Marca,[...] (Pujadó 2008)

(Arch of Triumph, Fondo, Spain/ Some people are vulgar, some are strange./ Poble Sec, Sant Roc, Entença/ One speaks alone, the other thinks./ Can Serra, Glòries Vallcarca/ Some read Marca [...])

Of special note is the reference to what riders read: sports newspapers, or highbrow authors such as Joyce or Rodoreda. Later in the song, Pujadó focuses on the metro as a cage, the encounter with different people, one rider speaking to himself or herself, others thinking, reading, exhausted/dreamy workers, the smell of sweat, being stepped on, pickpocketing, suicides, the pressure of bodies, distrust of immigrants, metro musicians, lack of blue sky, dreams, routine, views of a passing beautiful young woman, indifference, to end with another metaphor: the metro map (the riddle of metro station names) is an unfathomable grid, a giant word puzzle: 


\begin{abstract}
Via Júlia, Cornellà
Resignem-nos a deixar

Besòs Mar, Trinitat Vella

no resolta la graella

Sagrada Família, Encants

d'aquests encreuats gegants. (Pujadó 2008)

(Let's resign ourselves to leave $[\ldots]$ the grid unresolved $[\ldots]$ of this giant puzzle)
\end{abstract}

Pujadó's text introduces the underground as an unsolved problem, a hieroglyphic or labyrinth that one needs to solve. In both examples of poetry (Nens eutròpics and Pujadó), chaotic enumeration emphasizes the puzzling effect of the city on the surface. Their reorganization of station names opens a threshold that further amplifies this confusing meaning, calling attention to personal and social histories of riders and how they read the network.

It is useful to recall Pike's analysis of the underground and the labyrinth: 'The underworld follows neither the standard rules of time - for it endures eternally and mingles every epoch in its depths - nor those of space - for it is dark, supernatural, and labyrinthine in its construction' (Pike 2005: 191-92). This personalized version of the underground city map relates to personal and general history, and in the words of Michel de Certeau makes us the sole exegetist of a certain legacy:

Places are fragmentary and inward-turning histories, pasts that others are not allowed to read, accumulated times that can be unfolded but like stories held in reserve, remaining in an enigmatic state, symbolizations encysted in the pain or pleasure of the body. (1984: 108)

Comment [6]: As per journal style, quotes with more than 40 words are to be set as display quotes. Hence, please confirm the change from text to display quote. 
We might relate this last consideration with what de Certeau pointed out about city walking which applies to metro riding, and metro plan reading: with the use of synecdoche and asyndeton '[i]t practices the ellipsis of conjunctive loci' (1984: 101). Riding and reading become part of an intertwined activity characterized by its disjoint unity. The metro map becomes a sort of metro book. Moreover, it can be related to Rosalind Williams' observation that 'the subterranean environment is a technological one -but it is also a mental landscape, a social terrain, and an ideological map' (2008: 21).

\section{Disappeared spaces: Vanishing metro stations}

Michel de Certeau stated that proper names in the city link acts and footsteps, opening meanings and directions. They are symbolic devices that organize 'the topoi of a discourse on/of the city (legend, memory, and dream) in a way that also eludes urbanistic systematicity' (De Certeau 1984: 105). As we have seen before with the changes in stations names, proper names associated with space (toponyms, metro stations) make habitable or credible a place that is beautified with a word. They recall or conjure the ghosts (dead, or allegedly missing) that are still moving, crouching on the actions and bodies in motion, imposing an injunction arising from the other (a history), and altering functionalist identity creates on the spot of this erosion a non-place that undermines the law of the other.

In the case of metro networks there is a special condition of ghost stations, or Geisterbahnhöfe, a term used to describe the stations on Berlin's U-Bahn and S-Bahn metro networks that remained closed during Berlin's division from 1953 to 1989. It was an extreme situation in which passengers travelled through ghost stations, crossing the wall and encountering an underground world with a blurred temporality and geography (Links 1994). 
Similarly in Paris, during World War II, the French government closed all but 85 stations of the Paris network. The majority of stations were reopened after the war, though some stations less profitable remained closed. Some of these closed stations have been used as sets for films (Robert 1993; Symbioz 2015). Similar examples can be found in other cities. City Hall station in the New York subway decorated by Guastavino (Brennan 2002), or the Chamberí station in Madrid, which in 2008 was restored and became a Metro Museum (Masterson-Algar 2012).

An analogous situation has taken place in Barcelona. Some metro stations and even an underground shopping mall have disappeared. These include Bordeta, Correos and Fernando. Bordeta was closed as it was deemed unnecessary, being too close to Santa Eulàlia. Correos was part of the former L4 section at the end of Pau Claris. It was inaugurated in 1934 as a temporary station until metro network was extended to Estació de França. In 1972 it was closed because of its proximity to the Barceloneta station. The old stairs to the station can be seen in front of the main facade of the Post Office building. Fernando station is located between Liceu and Drassanes stations. It opened in 1946 and closed in 1968 for being very near the Liceu station, and to enable extension of Drassanes station. Other stations never opened: Banco, Gaudí and Travessera. Banco, built in Plaça Antonio Maura, was never opened to public use. According to popular belief it was made to carry with the money train, which ran only at night, shipments of money raised in all metro stations to the former Banco de España Barcelona headquarters (now Caixa Catalunya). The station had a direct access to the vault of the Bank (Barcelona Disused Stations 2014). This station was built fifteen years before the advent of the metro in Barcelona. It was a prevision by the 'Reforma' works of 1908, which consisted of opening a fast way - Via Laietana - of communication between the Eixample and the Port of Barcelona. The demolition was supposed to open an avenue 80 metres wide and 900 metres long. Planners built two tunnels under the new avenue hoping that they could be of use in a future underground metro system in the city. Over a decade 
later, and with the first metro line already operational, construction work began on a station that became known as Banc. However, the work was never finished. The engineers of the time made some serious miscalculations. According to Álex Reyes (2014), they built the platforms at the same level as the track, because they thought the metro would be like an underground tram. They neglected to take into account the machinery underneath, which meant they were later forced to lower the level of the track so that trains would be able to move along them.

Figure 6: Opening of Via Laietana.

Gaudí station can be seen in L5 between Sagrada Família and Hospital de Sant Pau stations. Built in 1968, the station is completely built, with platforms, walkways and escalators, but it was never opened. Located near the Sagrada Família, it was supposed to be a link with the old line 2 and provide easy access for tourists, but when the Sagrada FamiliaHorta section of L5 was built, it no longer made sense to open Gaudí. At the top level are the headquarters of the associations of retired workers from Transports Metropolitans de Barcelona (Barcelona Disused Stations 2014). It is remarkable that three of those stations correspond to important landmarks in Barcelona. Gaudí is the leading architect of the modernista movement and it is ironic that not a single metro station commemorates him. The other stations are linked to facilities - banking and the post service - stressing yet again the odd way in which Barcelona's metro system has been developed either without a plan or as an idiosyncratic solution to political needs. Line 9, the latest addition to Barcelona's metro network, has been born with a ghost station (Solé 2015). Interestingly, in his novel Solsona denounces an uncompleted ghost station. At the time, the station would have been named 'Cardenal Reig', which prompted his comment that 's'afegirà a la tradició clerical d'un 
nomenclàtor ple de sants, de cardenals i bisbes' ('it will be added to the tradition of clerical names of streets full of saints, bishops and cardinals') (2004: 218).

Another remarkable case of disappearance is that of a connecting corridor built under Pelai street. Jaume Sabater envisioned Avenida de la Luz (Avenue of Light) as an underground street, taking advantage of a disused tunnel excavated during the Universal Exhibition of 1929. It became the first underground shopping mall in Europe, which initially was to be extended to Urquinaona square (Xalabarder 1999). There was a public toilet that became a site for gay sexual encounters, a manufacturer of wafer biscuits with an aroma that filled all the space, a Pedro Montroy Masana wine shop, with a large mannequin dressed as an Aragonese pouring wine in a boot, a futbolin (foosball), and a cinema that for many years was a double feature and later became an X-rated theatre. After being closed for many years it is presently a dull Sephora store, and serves as a showcase of the city's transformation and its fading personality at the hands of globalization. Singer Loquillo, in his record ¿¿Dónde estabas tú en el 77?' ('Where were you in 1977') ([1984] 2008), included a song evoking the decadence of Avenida de la Luz in 1984 before it was closed.

\section{AVENIDA DE LA LUZ}

Es un buen lugar para acabar borracheras.

El Heartbreak hotel de mi ciudad.

El mito de ciudad sumergida,

a estas horas se vuelve real.

Estás solo, date cuenta, estás solo.

Avenida de la luz, no me mires con piedad.

Voy cegado por la luz de mi libre soledad.

$[\ldots]$ 
Avenida de la luz, el desierto empieza aquí [...]

(AVENUE OF LIGHT// It is a good place to stop drinking./ The heartbreak hotel in my city./ The myth of a submerged city,/ at this time it becomes real./ You are alone, you must realize, you're alone./ Avenue of Light, do not look at me with pity./ I'm blinded by the light of my free loneliness. /[...]/ Avenue of Light, the desert begins here $[\ldots]$ )

Echoing the emphasis on solitude and end of love in Elvis Presley's song 'Heartbreak Hotel', Loquillo stresses a blinding solitude at night and the fact that it encapsulates a submerged city, two of the main oxymoronic elements in the disappeared space: an avenue of light underneath the city, darkness under earth. ${ }^{5}$

The first paragraph of a short prose piece by Pere Gimferrer evokes fluorescent light as a mark of difference between two metro systems. Comparing FGC and the metro he evokes the subway experience as a moment of serenity in a hurried city life, focusing particularly on noise and the sense of imprisonment associated with travelling under the earth. The disparity in terms of lighting seems to refer to the connecting corridor between FGC and Gran Metro where ‘Avenida de la Luz' was once located:

Tot, al contrari, és, per definició, fosquedat i vida lucífuga, i claror neutra de clínica amb llums de neó si deixem l'àmbit del tren de Sarrià i ens endinsem a l'immens coval del Metro. És ací, verament, la caverna orba i remota, el ventrell fosc de la ciutat, els pulmons que esbufeguen en la negror soterrada. Lloc de passadissos immensos, on la gernació, espessa, flueix en silenci, sense cridòria, a un ritme igual, només amb una fressa constant de passos que bressen l'oïda (Everything, however, is by definition life by light and darkness, light and neutral neon clinical atmosphere when we leave the Sarrià railway 
area and enter the immense Metro cave. It is here, indeed, the blind and remote stomach of the dark city, lungs that puff in underground darkness. A place with immense corridors, where a thick crowd flows quietly, without shouting, at a steady pace, with a constant noise of steps that sings to the ear). (Gimferrer 1997: 329)

The emphasis here is on illumination. The underground city is perceived as the bowels of a body, with the masses moving mechanically in silence, echoing images from Fritz Lang's Metropolis.

Gabriel Ferrater's poem 'Amistat del braç’ ('Arm’s friendship’) evokes the unexpected promiscuity created during a subway ride. Of some attention is his metric choice (ten-syllable lines), which creates a sturdy rhythm, and how he expresses the heinous nature of inexperience and poor sensitivity by a young man, the voice in the poem. The allusion to the noise he hears when the carriage stops, breaking the sleepiness of the absent-minded protagonist:

El metro anava ple. Jo m'agafava

al barrot niquelat vora la porta.

Tenia el braç tibat, i tolerava

aquell pes tebi, persistent, a l'avantbraç.

Quedàvem poca gent quan vaig girar-me.

Era molt jove. Lletja i pobra, descarnada,

com una prima cabra mogrebina

que premia amb el front, tancant els ulls,

abalançada per tota carència, 
un braç encara de ningú, lliure i promiscu,

i no veia que ja algú es reprenia

i s'isolava al seu davant. Jo, massa jove

també, no havia après a reconèixer-me

en l'acceptació més que en la tria.

Vaig abandonar el braç, que no fos meu,

i no els vaig mirar més, anguniat

fins a l'estació, i el súbit trenc

d'una corda del cello, la més baixa.

(The subway was packed. I was grabbing/ the handrail by the door./ I had my arm tightened, and I endured/ that warm, persistent weight on my forearm./ There were few people left when I turned myself./ She was very young. Ugly and poor, emaciated,/ like a thin Maghreb goat/ pressing with her front, her eyes closed,/ leaning without energy,/ one arm still free and promiscuous/ and she did not realise that someone was already standing up/ and he was isolating himself in front of her. I was too young/ and I had not learned to recognize myself/ in the acceptance rather than choice./ I left that arm, which was not mine,/ and I did not look at them anymore, distressed/ until we reached the station, and the sudden noise/ of a cello string, the lowest one.) (Ferrater 1968: 46)

In the poem one can detect an echo of Baudelaire's 'À une passante' ('To a Passerby'), but more precisely of Jaime Gil de Biedma's poem 'Amistad a lo largo' ('Lasting Friendship'). The cello sound indicates the metro sudden stop, but also it may indicate a significant break experienced by the protagonist when the described situation occurs, because it interrupts the natural flow in the relationship of the protagonist with others and in particular with the young women, breaking away from innocence. Through the final metaphor, 'the poem becomes the 
formulation of an emblematic youth experience' (Cornudella 1988: 43), and also a moment of uncertainty and separation. The metro passenger car is used as an unexpected setting for proximity and intimacy combined with distance and unfamiliarity. It is a very familiar situation: a young man travelling in a packed metro realizes that somebody is leaning against his arm. When the metro reaches the final stop the young man realizes that it is a young woman, 'ugly and poor, emaciated', who with her eyes closed (half asleep?) in front of him creates this unforeseen intimate contact. Because of the young woman's nature ('like a thin Maghreb goat') we may infer that the poet evokes an encounter with a prostitute in a vanished metro stop, Fernando, at the heart of Barcelona's infamous red light district Barrio Chino (Chinese District). Ferrater's poem transforms the everyday, focusing on an event that could not have occurred in the streets above ground, and relates to the idea of the underground as 'the physical and conceptual trash heap of the modern world above' (Pike 2005: 5).

Vanished metro stations are related to readability and maps. They belong to a different category of city design, a conceptualization of the city that creates new senses and realities. Moreover, vanished metro stations belong to the reign of ruins, and they should be related to a sort of recuperation of the Renaissance's attraction for ruins. Brian Dillon has examined the twentieth-century ruin as the preserve of countless urban explorers and enthusiasts of decaying concrete that show their obsession in countless websites devoted to haunted asylums, silent foundries, vacant bunkers, and amputated subway stations. He explains that 'The ruin [...] seems almost a means of mourning the loss of the aesthetic itself' (Dillon 2005/06: 6). Abandoned metro stations are ruins of an industrial past, extremely expensive decisions in city planning that came to sticky ends, ghosts of forgotten spaces below earth that politicians and city branding experts alike love to forget. They are witnesses to a way of life already disappeared, traces of former everyday activities. Maybe it is literature (and cinema) that remains one of the ways of preserving a forgotten past and consequently giving an 
account of disappearance, and creating a catalogue of everyday life activities and locations. They are thresholds that help explain the transformation of underground urban space.

\section{Mythological views of metro riding}

The sheer amount of literature, film and popular music devoted to depicting the metro riding experience is truly impressive (Pike 2005; Ashford 2013). I am particularly interested in one manner of depiction that opens a threshold of a different nature: evocations of the subjective experience that takes place during a metro ride, in particular the comparisons with mythological situations in an obvious effort to uplift the banality of the situation. ${ }^{6}$ The use of classical mythology to elevate such an everyday activity is noteworthy. It could be linked to how early railways cloaked their novelty in classical garb (Pike 2005: 36), and it is a reminder of the vertical structure of modern technology and ancient mythology (Williams 2008: 67). Many texts about travelling by public transportation focus on the fact that they are short journeys in the company of strangers, thus emphasizing anonymity, combination of bright lights in stations with the darkness of tunnels, monotony of the journey, scrutiny of fellow travellers, reading, sleeping, daydreaming. David Welsh indicated two main themes of such travel: 'the infernal, in which the subterranean railway was perceived as a form of hell, abyss or underworld; and secondly, the utopian, in which the underground helps to integrate the modern metropolis by offering new freedoms' (Ashford 2013: 2).

Catalan avant-garde author Joan Salvat-Papasseit devoted several poems to the experience of tram and metro riding from a futurist perspective (Gavagnin 2007: 207). His emphasis is on limited space and time, that of the short travel, chance encounters, observation of female fellow passengers. Salvat is fascinated by the mixing of futurist industrial objects and the everyday, which provides a unique perspective to observe and suffer modernity. Eroticism always plays a role in Salvat's poetry. A poem such as 'Bitllet de quinze' ('Fifteen 
Ticket') finishes with a surprise: a breastfeeding woman squirts a passenger with milk. The observation from an almost voyeuristic perspective dominates the suspicions generated by the observation of the 'girl of the tram':

Que les cames se’t veuen

i la mitja és ben fina;

i tot el tram ets tu.

Però els ulls no se't veuen.

(I see the legs/ and the pantyhose is very thin;/ and you become the entire tram/ But one cannot see your eyes.) (Salvat 2006: 147)

The title of the poem ' 54045 ' refers to the palindromic ticket number, a sign of good luck. He combines a double cubist perspective - exterior and interior - evoking the experience of travelling by tram with attention to details of the route (Arc de Triomf) and the presence of figures of control (inspector and ticket collector). These figures provoke anxiety and discomfort, dispelling his condition of anonymity in the crowd.

This kind of approach to the experience of public transportation becomes the centre of two similar poems written in Paris, linked to the Métro. The fact that Barcelona did not have a metro until 1924 explains why when Salvat visited Paris in 1921 he reacted with such eagerness, writing two poems on the metro. ${ }^{7}$ Interestingly, he rides the Nord-Sud, which was central to avant-garde activities linking Montmartre and Montparnasse. The line's name was borrowed by Reverdy for an avant-garde review (Pike 2005: 64). These poems by Salvat are 'Passional al metro reflex n. ${ }^{\circ}$ '' ('Pasional on the Subway Reflection No. 1') and 'La femme aux oranges reflex n. ${ }^{\circ}$ '' ('Woman with Oranges Reflection No. 2'), included in L'irradiador del port $i$ les gavines ('The Port Radiator and the Seagulls') (1921). In the first one he uses 
exactly the same terms as in ' 54045 ' to describe the passenger car as a mythological monster with a powerful sexuality personified by Priapus, the god of fertility: 'La dinamo turgent mou els príaps de foc' ('the roaring engine moves the fiery Priapus') in '54045' becomes 'Antinous donzell príap perdut' ('Antinous a young lost Priapus’) (Salvat-Papasseit 2006: 60, 72). By metonymy and apposition he names a young lover in the metro, alluding to priapism and sexual arousal provoked by a female rider, Penelope. In the poem he describes a seduction between Antinous and Penelope that culminates when Penelope does not pay attention to her clothing and Antinous eats a rose right at the moment when the metro is under the Seine river: 'justament en passant sota la serp del Sena direcció Saint-Lazare' ('right under the Seine's snake direction Saint Lazare') (Salvat-Papasseit 2006: 72). Completing the sexual connotations of the character's name (from the Odyssey) and priapism, the river is perceived as a snake. In the second poem, the poet's lover rides the metro, sings what the poet calls the 'metro song', and performs a striptease under the earth according to different metro stations, thus indicating a movement or a ride in the line Nord-Sud:

\author{
I així la meva amada \\ ve assetjada a desdir: \\ Per això és que baixa a Rennes \\ es deixa la cotilla a Saint Michel, \\ i s'ajeu al meu bany de purpurina.
}

Banyera del NORD-SUD!

(and thus my lover/ is harassed:/ that's why she steps out at Rennes/ leaves her corset at Saint Michel/ and lies down in my glittery bathroom/Bathtub of the NORD-SUD!).

(Salvat-Papasseit 2006: 73) 
When the song ends, she shows her breasts to the other passengers. It is remarkable that Salvat includes the name of a metro station, Château d'eau, in the middle of the sentence, which is part of the line Nord-Sud and at the same time introduces the idea of squirting:

Finava la cançó quan la femme aux oranges, direcció

Château d'Eau, s'ha descobert la brusa i ha ensenyat els mugrons que eren com una llàntia de cremell.

(When the song was ending the femme aux Oranges direction/ Château d'Eau, has unbuttoned her blouse and shown her/ nipples/ they were like wax candle). (SalvatPapasseit 2006: 73)

In both poems an intimate scene between the lovers is depicted in a very public space. They are inscribed in a series, and they suggest another situation of the everyday noticeable in metro riding: the stark contrast between private and public, eye seduction, the creation of traces of our movements under earth not recognizable from the exterior. The movement of the metro, associated with the snake river, has strong sexual connotations.

Gimferrer also uses classic mythology in converting the metro riding experience to a metaphorical evocation of the harshness in life. In 'La vida subterrània' ('Life underground'), included in his Dietari, he points to the mechanical aspects of metro carriages surrounding the rider in a terrible noise that creates numbness. He also draws a fundamental distinction between the underworld and the surface: the prevalence of darkness and the shocking encounter with light when we reach the street. It is a way of portraying one significant aspect in the view from below (Pike 2005: 11): 
Però ja som en un vagó i hi ha un brunziment rítmic de pistons i carrils, èmbols i rodes; el metall, fent espurnes, colpeja, ràpid, el metall, i ens atueix els sentits aquest ressò fondíssim. Perdem, talment en un avió, la mesura del temps i de l'espai; cada cop ens serà, després, una sorpresa la claror sobtada del carrer (But we're in a car and there is a rhythmic sound of pistons and rails, valves and wheels; metal, producing sparks, hits, fast, metal, and this way the deep sound sleeps us. We lose, as in a plane, the sense of time and space, and every time the sudden light of the street surprises us). (Gimferrer 1997: 329)

The vertical aspect of metro riding is suggested through the association with flying in an airplane and losing sense of time and space. Gimferrer also points to the mythological characterization of the underworld by making associations with Roman mythology and Greek philosophy with references to Proserpina and Plato.

El viatge - com si haguéssim davallat al dominis de Proserpina, o tal vegada a la caverna de Plató- hauria hagut de purificar-nos. En el silenci individual silenci de la vida personal de cadascú, suspensió momentània, en un parèntesiaquests minuts, amb la vastedat del brogit de les locomotores subterrànies colpint, velocíssimes, la foscor del túnel, ens donen el que la vida diària ens estalvia sovint: un lleure per meditar sobre el lloc de l'home en el cicle còsmic, que alhora l'enclou, l'envolta i li és extern. (The trip - as we had fallen in the domains of Proserpina, or perhaps Plato's cave - should have purified us. In individual silence - silence in each one of us personal life, in a momentarily suspended parenthesis - these minutes, with the vast roar of the engines hitting at great speed the underground tunnel's darkness, give us what daily life spares 
us often: a leisure to meditate on man's place in the cosmic cycle, that at the same time encompasses, surrounds and it is external him). (Gimferrer 1997:

Thanks to the references to Proserpina's underworld and Plato's cave, the subway riding experience is elevated to a more sophisticated level, and we can understand why the metro can be an unlikely refuge for a philosophical meditation about the place of human beings in the universe. Proserpina introduces the association with the underworld realm. With her mother Ceres, and along with the springtime growth of crops and the cycle of life, she refers to death and rebirth, or renewal. There is also a contradiction between public and private space, the world over and under the city. Gimferrer's metro ride adapts a heroic allure achieving a rare success: finding a very public and noisy place where there is room for metaphysical meditation. As stated by Williams, 'the subterranean environment is a technological one - but it is also a mental landscape, a social terrain, and an ideological map' (2008: 21). Gimferrer's prose acknowledges and combines all three environments. Both authors provide a glimpse into instances of disappearance (privacy, quietness) through the mixing of private and public spaces, or linking the vertical city.

\section{Conclusion}

Imagery of the underground is grouped into two distinct yet complementary categories: 'a discourse of segregation and elimination, and a discourse of incorporation and recycling' (Pike 2007: 6). Although Pike applies this categorization to nineteenth-century London and Paris, it still bears some truth in the case of Barcelona, with its backwardness and late arrival to modernity, and the authors discussed here exemplify both trends. Paying attention to the 
metro riding experience leads one to reflect upon the disappearance of buried and forgotten urban spaces. In fact, one must reflect on the rapidity with which urban space evolves in contemporary cities, which only adds to the unravelling of memories the city space evokes and how it affects everyday life, changing unperceivably how we are in the world and how we relate to our environment. Thompson has stated that 'the aesthetics of disappearance is intrinsically linked to the aesthetics of change as urban spaces evolve' (2015: 162). As stressed by Siegfried Kracauer in his essay 'Street without Memory' (1932), one's memories can be shocked into being, as familiar landmarks disappear, or are erased entirely by the destruction of the space in which they stood. Such erasure, for Kracauer, was the installation of an eternal now, a constant present-ness. According to Thompson, it is similar to Baudrillard's fear: 'that memory itself will be eradicated by the imposition of simulated versions of the past, synthetic histories engendered by a process of "museification" that produces an officially sanctioned form of cultural memory' (2015: 162). As stated by Baudrillard, 'It is no longer buildings which burn or cities which are laid waste; it is the radio relays of our memories you can hear crackling' (Thompson 2015: 162). Unravelling hidden spaces, and their presence in a physical and emotional network, helps to create a map of the city and of its inhabitants' past, exploring space and becoming witness of the changes in everyday life. The awareness of metro maps introduced by the songs examined, the attention to hidden and disappeared underground spaces in other texts, and the drive to connect the metro experience with mythological references all are crucial components in the cartography of disappearance.

The topics discussed here are fragmentary thresholds that reflect the real underground city, one constructed with uncertainties and errors. We have observed instances of misreading, disappearance and transformation through mythological references that portray a hidden map under the visible city. Because cartography is more than a selected list of names and their 
connecting coloured lines, Barcelona's metro map can be read in different ways, thus providing a different portray of the city. Metro maps and rides create a different sense of time and a different way of reading the underground and its relationship with the surface. The underground is a special setting for everyday life where communications and human interaction acquire a different status. The legibility of the metro map belies a problematic way of reading - it is only in attending to the metro's hidden meanings that we may fully understand it, thus catching a glimpse of our past and present everyday.

\section{References}

Ashford, D. (2013), London Underground: A Cultural Geography, Liverpool: Liverpool University Press.

Augé, M. (2002), In the Metro, Minneapolis: Minnesota University Press.

(2008), Le Métro Revisité, Paris: Seuil.

Balaguer, V. (1865), Las calles de Barcelona, 2 vols., Barcelona: Salvador Manero.

Barcelona Disused Stations (2014), http://www.trackrunners.net/stories/disused-stations/. Accessed 23 February 2015.

Bleiler, E. F. (1983), The Guide to Supernatural Fiction, Kent: Kent State University Press. 
Brennan, J. (2002), 'Abandoned stations. City Hall. (IRT)',

http://www.columbia.edu/ brennan/abandoned/cityirt.html. Accessed 15 January 2015.

Brooks, M. W. (1997), Subway City: Riding the Trains, Reading New York, New Brunswick: Rutgers University Press.

Cornudella, J. (1988), 'Estudi introductori', in G. Ferrater (ed.), Vers i prosa, València: Tres i Quatre, pp.9-47.

Cortázar, J. (1994), Cuentos Completos, Madrid: Alfaguara.

Certeau, M. de (1984), The Practice of Everyday Life (trans. S. Rendall), Berkeley:

California University Press.

Deiros Quintanilla, I. (2012), El finançament de les grans obres d'infraestructures ferroviàries: el cas de la línia 9 (722-tes-ca-5590), Barcelona: Universitat Politècnica de Catalunya.

Denil, M. (2011), 'The Search for a radical cartography’, Cartographic Perspectives, 0.68, pp. 7-28, http://cartographicperspectives.org/index.php/journal/article/view/cp68deni1/5. Accessed 15 July 2014.

Dillon, B. (2005/06), ‘Fragments from a History of Ruin', Cabinet, 20, Winter, http://www.cabinetmagazine.org/issues/20/dillon.php. Accessed 15 February 2015. 
Els Nens Eutròfics (2013), 'Subterrània', En helicòpter, Music CD, Barcelona: La Casa Calba Ed. http://elsnenseutrofics.bandcamp.com/track/subterr-nia. Accessed 15 February 2015.

Fabre, J. and Huertas, J. M. (1982), Carrers de Barcelona: Com han evolucionat els seus noms, Barcelona: Edhasa.

Ferrater, G. (1968), Les dones i els dies, Barcelona: Edicions 62.

fgc150 (2013), '150 anys 1863-2013 Tren de Sarrià', http://www.fgc150.cat/index.asp. Accessed 15 February 2015.

Gavagnin, G. (2007), 'Mites i objectes futuristes en la poesia de Salvat-Papasseit: apunts de lectura comparada', Estudis romànics, 29, pp. 193-211.

Gaziel (1929), 'Pequeña elegía urbana', La Vanguardia, 26 April, p. 5.

Gilloch, G. (2004), 'Impromptus of a great city: Siegfried Kracauer’s Strassen in Berlin und Anderswo', in M. Hvattum and C. Hermansen (eds), Tracing Modernity: Manifestations of the Modern in Architecture and the City, London: Routledge, pp. $291-306$

Guerola, J. (2004), ‘Terradas y la construcción del túnel del Metro Transversal de Barcelona’, Quark, 31, pp. 85-94.

Gimferrer, P. (1997), Dietari Complet, 1, Barcelona: Edicions 62.

\section{shilpa 24/11/2016 17:37}

Comment [15]: Please provide format, name and city location of the label. When you do this please follow the following format exactly, including connecting punctuation: Els Nens Eutròfics (2013), 'Subterrània', En helicòpter, xxxxx, city: Label. Enric Bou Maqueda 2/12/2016 16:30

Formatted: Font:12 pt Enric Bou Maqueda 2/12/2016 16:30

Formatted: Font:(Default) Times New Roman, 12 pt

Enric Bou Maqueda 2/12/2016 16:30

Formatted: Line spacing: single Unknown

Field Code Changed

\section{Enric Bou Maqueda 2/12/2016 16:33}

Comment [16]: Issue 29

\section{shilpa 3/13/1992 14:44}

Comment [17]: Please provide issue number.

\section{shilpa 3/13/1992 14:46}

Comment [18]: Please provide page number. When you do this please follow the following format exactly, including

connecting punctuation: Gaziel (1929),

'Pequeña elegía urbana', La Vanguardia, 26 April, p. xx.

Enric Bou Maqueda 2/12/2016 16:34

Deleted:

Comment [20]: Please provide issue number. 
Latorre, E. (2015), 'El nyap de la línia 9 del metro: costos per triplicat, estacions privatitzades i anys de retard', Critic. Periodisme d'investigació. http://www.elcritic.cat/investigacio/el-nyap-de-la-linia-9-del-metro-costos-pertriplicat-estacions-privatizades-i-anys-de-retard-4394. Accessed 10 June 2016.

Links, C. (1994), Berliner Geisterbahnhöfe: The Berlin Ghost Stations: Les gares fantômes, Berlin: Ch. Links Verlag.

List of metro systems (2015), http://en.wikipedia.org/wiki/List_of metro systems. Accessed 15 February 2015.

Loquillo y Los Trogloditas ([1984] 2008), El Ritmo del Garaje/Donde Estabas Tu en el 77, Barcelona: Warner Music Spain.

Maragall, J. (1912), Obres Completes. Escrits en prosa, Barcelona: Gustau Gili, editor.

Masterson-Algar, A. (2012), 'Digging Madrid: A descent into Madrid's subway museum Andén 0', in B. Fraser and S. Spalding (eds), Trains, Culture, and Mobility: Riding the Rails, Lanham: Lexington Books, pp. 205-32. widow/orphan control, Don't adjust space between Latin and Asian text, Don't adjust space between Asian text and numbers

Enric Bou Maqueda 2/12/2016 16:17

Formatted: Font:(Default) Times New

Roman, Not Bold

\section{shilpa 24/11/2016 17:37}

Comment [21]: Please provide volume and issue number and page range.. When you do this please follow the following format exactly, including connecting punctuation: Latorre, E. (2015), 'El nyap de la línia 9 del metro: costos per triplicat, estacions privatitzades $\mathrm{i}$ anys de retard', Crític. Periodisme d'investigació, xx:xx, pp $\mathrm{xx}-\mathrm{xx}$. 
(2014), 'The subte as looking machine into the city: Moebius' trajectory through Buenos Aires', Transfers, 4:2, pp. 68-85.

Nervi, M. (2011), 'The Kafka Project. Reise August/September 1911', http://www.kafka.org/index.php?rtbas1911. Accessed 1 April 2015.

Pike, D. L. (2005), Subterranean Cities: The World Beneath Paris and London, 1800-1945, Ithaca: Cornell University Press.

(2007), Metropolis on the Styx: The Underworlds of Modern Urban Culture, 18002001, Ithaca: Cornell University Press.

Pujadó, M. (2008), Frontissa (1999/2002), Barcelona: Discmedi S.A.

Quintana, L. (2009), 'Didàctica dels carrers: Barcelona al segle XX', in C. Carreras and S. Moreno (eds), Llegint pedres, escrivint ciutats: Unes visions literàries de la ciutat, Lleida: Pagès, pp. 23-35.

Reyes, A. (2014), ‘Gran Metropolitano de Barcelona', http://www.granmetro.es/. Accessed 1 April 2015.

Robert, J. (1983), Notre Métro, Paris: Jean Robert.

Salmerón i Bosch, C. (1992), El metro de Barcelona: Història del ferrocarril metropolità de Barcelona, Barcelona: Términus. 
Salvat-Papasseit, J. (2006), Obra completa: Poesia i prosa, Barcelona: Cercle de lectors.

Schwandl, R. (2001), Metros in Spain: The Underground Railways of Madrid, Barcelona, Valencia and Bilbao, London: Capital Transport Publishing.

Sheringham, M. (2006), Everyday Life: Theories and Practices from Surrealism to the Present, Oxford: Oxford University Press.

Solé, A. (2015), 'Rodalies. Mal servei i inversió nul·la', Ara, 21 March, pp. 4-6.

Solsona, R. (2004), Línia Blava, Barcelona: Columna.

Subirana, J. (2014), 'Batejar carrers, imaginar països. Raons del nomenclàtor, de Víctor Balaguer a Barcelona'92', Journal of Iberian and Latin American Studies, 198:3, pp. $1-14$.

Symbioz (2015), 'Les stations oubliés', http://www.symbioz.net/index.php?id=34. Accessed 5 April 2015.

Thompson, Z. (2015), Urban Constellations: Spaces of Cultural Regeneration in PostIndustrial Britain, Farnham: Ashgate.

trackrunners (2014), ‘All Metro. All City’, http://www.trackrunners.net/. Accessed 15 March 2015. 
Tracy, W. (1986), Letters of Credit, London: Gordon Fraser Gallery Ltd.

Valls, M. (2012), La Barcelona Subterrània, Barcelona: Editorial Mediterrània.

Williams, R. (2008), Notes on the Underground, An Essay on Technology, Society, and the Imagination, Cambridge: The MIT Press.

Xalabarder, M. (1999), 'La Avenida de la Luz, una calle subterránea en Barcelona', Estudios geográficos, LX, 236, pp. 487-512.

\section{Contributor details}

Enric Bou is Professor of Spanish and Catalan literature at the Università Ca' Foscari di Venezia. He has been Professor of Hispanic Studies at Brown University (1996-2011). His teaching and research interests cover a broad range of twentieth-century Spanish Peninsular and Catalan literature but particularly involving poetry, autobiography, city and literature, and Spanish film. His latest books are Daliccionario. Objetos, mitos y símbolos de Salvador Dali (Tusquets, 2004), the edition of Pedro Salinas' Obras Completas (3 vols, Cátedra 2007), Panorama critic de la literatura catalana Segle XX. V-VI (2 vols, Vicens Vives 2009-10), an essay about space and literature: Invention of Space. City, Travel and Literature (VervuertIberoamericana, 2013). He is the Editor of Catalan Review and Rassegna Iberistica.

\section{Contact:}

Dipartimento di Studi Linguistici e Culturali Comparati, Università Ca' Foscari Venezia, Dorsoduro 3199, Venezia 30123, Italy.

E-mail: enric.bou@unive.it 
Enric Bou has asserted his right under the Copyright, Designs and Patents Act, 1988, to be identified as the author of this work in the format that was submitted to Intellect Ltd.

Notes

${ }^{1}$ The opening of the southern segment in Line 9 is the last episode in a disgraceful history (Latorre, Deiros Quintanilla).

${ }^{2}$ A comparison of name changes juxtaposing the city underground and the city on the surface would be useful. For name changes (see Fabre and Huertas 1982).

${ }^{3}$ There have been initiatives to map out Barcelona's underground from different perspectives than traditional maps (Valls 2012).

${ }^{4}$ It can be related to poems based on a toponym list, such as Miguel de Unamuno's ‘Toponimia hispánica', Blas de Otero’s 'Espejo de España', Joan Brossa in Poemes civils or Vicent Andrés Estellés' 'Cos mortal' in Llibre de meravelles.

${ }^{5}$ Following the example of London and Paris the underground is used as the cinematic setting for thrillers such as in Francisco Pérez-Dolz's A tiro limpio (1963). In two films, one by Bigas Luna, Bilbao (1978), another by Francesc Betriu, Sinatra (1988), ‘Avenida de la Luz' is used to emphasize separation and marginality of the film's characters. In all three cases several scenes' images operate as witness of disappearance.

${ }^{6}$ For an extensive list of stories on the metro in English see 'Tubes, Subways, and Cars' under 'Railroads' (Bleiler 1983: 598). Brooks provides a comprehensive approach to literature and art on NYC's subway. 
$\overline{{ }^{7} \text { Salvat-Papasseit died in } 1924 \text { and he did not see underground transportation in his own city. }}$

In 1921, during his brief stay in Paris he wrote in a letter to a friend: 'But the Metro is better.

You see. Paris has become more than ever avantgardiste' (Salvat-Papasseit 2006: 492). 